\title{
Adalet Ağaoğlu'nun Dar Zamanlar Üçlemesinde Hafıza, Tarih ve Kimlik
}

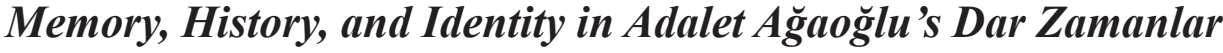 Trilogy}

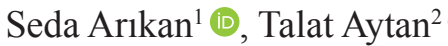

${ }^{1}$ Doç. Dr., Fırat Üniversitesi, Batı Dilleri ve Edebiyatları Bölümü, Elazığ, Türkiye 2Doç. Dr., Yıldız Teknik Üniversitesi, Türkçe ve Sosyal Bilimler Eğitimi Bölümü, İstanbul, Türkiye

ORCID: S.A. 0000-0003-4190-9205, T.A. 0000-0001-9778-8970

Sorumlu yazar/Corresponding author: Seda Arıkan,

Fırat Üniversitesi, Batı Dilleri ve Edebiyatları Bölümü, Elazığ, Türkiye

E-mail: bulutsedaarikan@gmail.com

Başvuru/Submitted: 11.09.2021

Revizyon Talebi/Revision Requested: 09.11.2021 Son Revizyon/Last Revision Received: 07.12.2021 Kabul/Accepted: 08.12.2021

Online Yayın/Published Online: 14.12.2021

\section{Atıf/Citation:}

Arikan, S., \& Aytan, T. (2021). Adalet Ağaoğlu'nun Dar Zamanlar Üçlemesinde Hafiza, Tarih ve Kimlik. TUDED, 61(2), 541-559. https://doi.org/10.26650/TUDED2021-993976

\section{ÖZET}

Adalet Ağaoğlu'nun Dar Zamanlar adlı üçlemesi hafıza, tarih ve kimlik konularını, anlatısına Cumhuriyet idealleriyle büyümüş küçük bir kız olarak başlayan ve Türk tarihinin Cumhuriyet sonrası çalkantılı zamanlarında bir akademisyen olan başkahraman Aysel'in gelişimi üzerinden işlemektedir. Cumhuriyet sonrası Türkiye'sinin tarihsel olayları bağlamında, bireyin ve toplumun hafıza ve kimlik oluşumunu hem bireysel hem toplumsal tarihi hatırlama ödevi üzerinden değerlendiren bu üçleme, toplumsal ve bireysel amneziye karşı önemli bir eleştiri sunmaktadır. Ağaoğlu'nun bu üçlemesi, özelde bireyin genelde ise toplumun tarihini ve kimliğini inşa etmek için bireysel ve toplumsal hafızanın nasıl yeniden gözden geçirilmesi gerektiğini tasvir eder. Bu noktada Ağaoğlu'nun Dar Zamanlar üçlemesi, yirminci yüzyıldan bu yana üzerine önemli çalışmalar yapılan hafıza etiği tartışmalarını bünyesinde barındırmaktadır. Üçlemenin ilk romanı Ölmeye Yatmak, bireysel ve toplumsal unutmaya karșı hatırlama etiğini sunarken ikinci roman Bir Dügün Gecesi geçmişteki olayları unutmayı tercih eden bireylerin sadece kendilerine değil, kendi toplumlarına da zarar vereceklerini ortaya koymaktadır. Üçlemenin son romanı Hayır... ise, unutmayı delilik olarak tanımlar ve tarihi yeniden gözden geçirerek unutmaya karşı durabilecek Yeni İnsanın doğuşunu önerir. Bu bağlamda, bu çalışma Ağaoğlu'nun Dar Zamanlar üçlemesinde unutma ve hatırlamanın ahlaki yönüne odaklanmakta ve hafıza etiği teorilerine atıfta bulunarak bireysel ve toplumsal hafızayı milli tarih ve kimlik ilişkisi içinde incelemeyi amaçlamaktadır.

Anahtar Kelimeler: Adalet Ağaoğlu, Dar Zamanlar üçlemesi, hafıza, tarih, kimlik

\section{ABSTRACT}

Adalet Ağaoğlu's trilogy Dar Zamanlar [Narrow Times] addresses memory, history, and identity by depicting the development of its protagonist, Aysel, who begins her narrative as a little girl raised with Republican ideals and becomes an academician in the turbulent times of post-republican Turkish history. Evaluating the memory and identity formation of the individual and society in the context of the historical events of post-republic Turkey, this trilogy presents an essential critique of social and individual amnesia. The trilogy depicts how the individual and social memory should be revisited to construct the history and identity of individuals in particular as well as the society as a whole. At this point, Ağaoğlu's trilogy embodies the debates on the ethics of memory, a topic on which significant studies have been conducted since the twentieth century. The first novel of the trilogy, Ölmeye Yatmak [Lying Down to Die], 
addresses the ethics of remembering against individual and social amnesia. The second novel, Bir Dügün Gecesi [A Wedding Night], reveals how individuals who prefer to forget past events would cause harm to themselves as well as to their society. Finally, the last novel of the trilogy, Haylr... [No...], defines forgetting as an act of insanity and proposes the birth of a New Human who could eliminate oblivion by revisiting history. In this respect, this study focuses on the moral side of forgetting and remembering in Ağaoğlu's Dar Zamanlar trilogy and aims to examine individual and social memory in terms of its relation to national history and identity by referring to the theories of the ethics of memory.

Keywords: Adalet Ağaoğlu, Dar Zamanlar trilogy, memory, history, identity

\section{EXTENDED ABSTRACT}

Dar Zamanlar [Narrow Times], the trilogy by Adalet Ağaoğlu-one of the leading women writers of twentieth-century Turkish literature-focuses on the memory-making of the individual and society within the framework of a historical narrative. These novels, which deal with the historical events of post-republic Turkey in relation to the formation of the individual's identity, offer a strong critique of social and individual amnesia. In the first novel, Ölmeye Yatmak [Lying Down to Die], the protagonist Aysel's consideration of her past in terms of an ontological questioning reflects the need for individuals to reconstruct their identities by revisiting their individual and social histories. In this sense, Ağaoğlu's conceptualization of a protagonist who is an academician questioning the role of memory in individual as well as social lives makes the trilogy bilateral. The first novel, which offers a kind of duty and ethics of remembering set against individual and social amnesia, suggests that it is the society's responsibility to ensure remembrance of the past by providing detailed historical accounts of the country and its people. In the first novel, the readers witness the protagonist Aysel confronting her past, together with the memories associated with the same, and re-rooting herself in life; consequently, the second novel Bir Düğün Gecesi [A Wedding Night] is based on the idea that individuals who take refuge in oblivion as well as a society comprising such individuals are subject to inevitable tragedy. Ağaoğlu, who reflects the characters' mental interrogation of their past and memories by using inner monologues and stream of consciousness technique, considers forgetting as an immoral act in this novel. Although the duty of forgetting - which prevents individuals from forming their identities and, as a result, destroys the identity of the society — is advocated as a necessary action by some philosophers of the ethics of memory, Ağaoğlu presents a contrary perspective. The fact that individual memoirs of the characters mirror how social classes were formed, particularly in the post-republican period, transports the narrative from the individual to the social sphere. In this respect, Bir Dü̈g̈̈n Gecesi reinforces the moral aspect of memory and remembrance, emphasizing that there is a moral aspect associated with confronting and forgiving the past. The last novel of the trilogy, Haylr... [No...], highlights the association of forgetting with insanity and reviews "psychosis" through a cyclical narrative technique. This novel, which revisits the rituals of forgetting and remembering practiced by Professor Aysel and the other characters, reveals that only by remembering does an individual gain an identity. The formation of individual and social memory ensures that justice is served to the individual as well as the society; the injustice that occurs with forgetting is perceived as a threat to identity formation. Forgetting, which is presented as the equivalent of insanity in Hayl ..., 
is considered through the theme that identities can be restored only through a revisit to the past and an evaluation of the memories associated with the same. It concludes by delineating the act of remembering through the rise of the figure of a New Human who can create her/ his own memory by reuniting with their past. Thus, in Ağaoğlu's trilogy, the Turkish reader is recommended to address individual and social amnesia to construct an identity that could only be attained with memory. In this respect, this study which deals with Ağaoğlu's Dar Zamanlar trilogy through philosophical theories focusing on the moral aspects of forgetting and remembering aims to examine individual and social memory in the context of questioning history and identity. Within this aim, the theories related to the ethics of memory, a very significant field in memory studies, have been taken into consideration, and in this context, the ethics of forgetting and the ethics of remembering have been referenced to depict Ağaoğlu's evaluation of memory, history, and identity. 


\section{GíRIŞ}

Yirminci yüzyıl Türk edebiyatı, roman türünün hızlı gelişimiyle karşı karşıya iken Türk romancılar modernist edebiyat yazınından postmodernist edebiyat yazınına uzanan bir sürece tanıklık ve faillik etmişlerdir. Bu yüzyılın önde gelen Türk kadın yazarlarından Adalet Ağaoğlu (1929-2020) kurgusal ve kurgu-dışı eserleri ile milenyum sonrası çağa da tanıklık etmiş, dahası hem kendi nesli hem de sonraki nesiller için bir önceki yüzyılı tanıtma, hatırlatma ve yeniden yazma görevi üstlenmiştir (Uğurlu, 2003; Eronat, 2004; Topaloğlu, 2005; Cuşa, 2017). Ağaoğlu'nun Cumhuriyet sonrası Türkiye'sinin sosyal, politik, ekonomik, kültürel ve ahlaki tüm paradigmalarına ışık tuttuğu; "istikrarsız bir tarih, indili çıktılı bir siyasal, toplumsal iklimde bunalan, hatta boğulan insanların kitlenmiş dünyalarını açmak, dil tutukluğunu aşmak isteği” ile yazdığı (Ağaoğlu, 1996, s.167) Dar Zamanlar üçlemesi hafıza, tarih ve kimlik üçgeninde örülmüş üç roman1; Ölmeye Yatmak (1974), Bir Dügü̈n Gecesi (1976), ve Hayır... (1987)'1 içermektedir. Özellikle ilk iki romanda, iç monolog ve bilinç akışı gibi modernist teknikler kullanılırken son roman üstkurgusal özelliği ile postmodernist bir yaklaşımı barındırmaktadır. Roman teknikleri açısından oldukça zengin olan bu üçlemenin "Edebiyatın toplumsal işlevi nedir?” sorusu bağlamındaki önemi, edebiyatın tarih ve hafıza ile geçişli olan özelliği üzerine kuruludur. Postmodern edebiyatın bilinçli ve politik bir tercih olarak yeniden tarih yazımı üzerine yoğunlaşması, unutulan ya da sistematik olarak unutturulan bireysel ve ortak (kolektif) tarihin hafıza teorileri üzerinden yeniden tartışılmasına dayanır. Bu bağlamda edebiyat, bireysel ve toplumsal kimliğin gerektirdiği tarih ve "tarihin rahmi olarak" tanımlanan hafıza (Ricouer, 2004, s.95) olguları ile kaçınılmaz bir ilişkiye ve iş birliğine sahiptir. Ağaoğlu’nun üçlemesi de bireysel ve toplumsal hafizanın örüldüğü, bu bakımdan bireysel ve toplumsal tarihin ve kimliğin yeniden kurulduğu bir anlatı olması açısından oldukça önemlidir.

Dar Zamanlar'da edebiyatın bireysel ve toplumsal hafıza ile bağı, birçok edebiyat teorisyeninin edebiyatı "kültürel hafızanın mimesisi" olarak tanımlaması ile bağlantılıdır. Erll ve Rigney’e göre, “edebiyat ortak hafizanın epistemolojisi, etiği ve mekanizması üzerine derin bir şekilde düşünerek geçmişin ve geçmişle ilgili formların yorumlanması konusunda tarihçiler ve sosyologlar ile diyaloğa girer" (2006, s.113). Bu bağlamda Dar Zamanlar, roman türünün tarihsel ve sosyolojik alanlarla çoklu bir diyaloğudur. Özellikle, 1930’lardan başlayarak Cumhuriyet sonrası Türkiye'sine ayna tutan üçlemenin ilk romanı Ölmeye Yatmak hem bireysel hem de ulusal ve uluslararası tarihi, metinlerarası bir teknik kullanarak okuyucuya yansıtır. Roman kahramanlarının bireysel tarihleri Ağaoğlu'nun bir yazar için de çok önemli olduğunu belirttiği günlük ve mektup yazımı (Can, 2019) ile metinlerarası bir şekle bürünürken televizyonun henüz çok yaygın olmadığı ortak tarihî dönem, özellikle gazete kupürleri ve ilanları üzerinden verilir.

Renate Lachmann'ın “bir metnin hafızası onun metinlerarasılığıdır” (2004, s.173) tespiti, üçlemenin özellikle ilk romanında kendini göstermektedir. Cumhuriyet Türkiye'sinde "yeni bir kuşak"1n doğumu $(O ̈ Y, 29)$ ile başlayan anlatı, paralel olarak tarihsel bir anlatı ile diyaloğa girer. Sosyo-politik ulusal anlatılar dünya tarihinden notlarla iç içe geçerken ortak tarih hem 
hatırlatılır hem de yeniden kurulur. Sıtmadan korunmak için piyasaya sürülen ilaç, yeni gelen Blaupunkt radyolar, odundan kömüre geçiş dönemi (ÖY, 32), o dönem gösterimdeki filmler $(\ddot{O} Y, 33)$, Ankara Gençlik Parkı'nın yapımına başlanması $(\ddot{O} Y, 34)$, Ankara' da yeni radyo istasyonunun ve Halk Bankası'nın açılması (ÖY, 34-35) ile bağlantılı ayrıntılı bir tarihsel anlatı politikacıların, düşünürlerin ve yüksek rütbeli askerlerin söylemlerinden parçalar ile sunulmaktadır. Ulusal tarih anlatısı, uluslararası bir düzeyde dünya tarihinde olup bitenlerle iç içe geçmiştir. Üstelik bu tarihî anlatı sadece politika ya da ekonomi gibi başat kabul edilen alanları değil moda ve spor dâhil birçok gündemi içermektedir. Paris'te Coty'nin yarattığı yeni pudra renklerinden $(\ddot{O} Y, 36)$ Amerikan Efkârı Umumiye Enstitüsü'nün Amerikalıların hangi ulusu sevdikleri üzerine yapılan ankete $\operatorname{kadar}(\ddot{O} Y, 37)$ birçok tarihi bilgi çoğunlukla gazete haberlerinin bir aktarımı olarak karşımıza çıkar. Ağaoğlu romanın ilerleyen bölümlerinde ise, Türkiye'de kaçak olarak okunan kitapları listeler, moda olan kadın kıyafetlerini tarif eder, etin ve kahvenin fiyatından bahseder, sinemalarda gösterilen filmleri fiyatları ile birlikte verir (ÖY, 358, 359).

Ağaoğlu, BBC Türkçede yayımlanan bir röportajında, Ölmeye Yatmak romanında sadece ülkede ve dünyada neler yaşandığını yansıtabilmek için değil aynı zamanda “1938'de ilkokulu bitirmiş çocukların dilini bulmak" için ayrıntılı bir arşiv taraması yaptığından bahseder (Abakan, 1993). Bu bağlamda, realist ve mimetik bir anlatı ile romanı tarihsel bir çerçeveye oturtarak bireysel ve ortak tarih yazımının hafıza oluşumuna, hafıza ile de bireysel ve ortak kimliklerin yaratımına uzanan bir zincirin gerekliliğini metinlerarası bir edebiyat yazını ile vurgular. Ağaoğlu, üçlemesinde hem bireysel hem de ulusal ve uluslararası toplumsal hafızaya geri dönerek hâlin ve yarının hafızasını oluşturmanın özellikle etik değerini vurgulamaktadır. Hem bireyin hem de toplumun tarihi üzerinden kimlik inşaları, üçlemede hafiza olgusu ile birbirine bağlanırken karakterler ve olaylar hatırlamanın ya da unutmanın etik değeri üzerine okuyucuya önemli fikirler sunmaktadır. Bu açıdan Dar Zamanlar, bireyin ve toplumun hafızasında depolanmış, kimi zaman bilinçli kimi zaman ise bilinçdışı olarak bastırılmış veya silinmeye çalışılmış bir tarihi ve hafızayı geri getirmenin etik yönünü vurgulayan bir tür tarih ve hafıza yazımı olarak değerlendirilmelidir.

Erll'ün belirttiği gibi “Edebiyat, hafiza kültüründe bir boşluğu doldurur [...] geçmişle ilişkilerimizin unutulmuş ve bastırılmış, aynı zamanda fark edilmemiş bilinçdışı ve kasıtsız yönlerine atıfta bulunma yeteneğine ve eğilimine sahiptir" (2011, s.153). Bu bağlamda, tarih ve hafıza yaratımı olarak Ağaoğlu'nun üçlemesinin işlevi de bilinçli ya da bilinçdışı şekilde unutulan veya unutturulan bireysel ve ortak tarihi açı̆̆a çıkarmak, böylece özgün bir kimlik oluşturmanın yolunu aydınlatmaktır. Birey ve toplum olarak çıkılacak bu yolda, Ağaoğlu Ölmeye Yatmak romanı ile hatırlamanın etik bir görev olduğunu, Bir Dügüun Gecesi ile unutmanın yıkıma neden olduğu yaşamları ve geçmişi bastırarak onun yasını tutmayanların bu etik görevi yerine getiremediklerini, Hayır ... romanı ile de aynı döngü içerisinde tarihiyle ya da geçmişiyle yüzleşmeyenlerin hem kendilerine hem de ötekine adil davranmadığı için deliliğe varan bir buhrana sürüklenirken tarihi ve hafızayı yeniden yazanların "yeni bir insan" olmaya uzanan serüvenine bizleri davet etmektedir. 


\section{Bireysel ve Toplumsal Amneziye Karşı Hatırlama Görevi}

Ölmeye Yatmak, Cumhuriyet idealleri ile yetişmiş bir kız çocuğunun toplumsal sorunlara karşı savaş açan bir akademisyen olma sürecini anlatmakla birlikte hem bireysel hem de toplumsal buhranlar nedeniyle ortaya çıkan bir iç hesaplaşma ve bir hatırlama ritüelidir. Ağaoğlu, sadece üçlemenin bu ilk kitabı ile değil diğer iki kitapta da "toplumun sosyal, ekonomik ve [politik] dinamikleri ile zihinden çıkarılan hafıza" olarak tanımlanan toplumsal amneziye (Jacoby, 1975, s.4) karşı, açık bir şekilde topluma hatırlama görevini salık verir. Cumhuriyet sonrası sosyal, politik ve ekonomik birçok gelişme bu nedenle romanda ayrıntılı bir şekilde kronolojik olarak verilmektedir. TBMM'nin Birleşmiş Milletler Topluluğu'na katıldığımızı ve böylece “artık özgür ve uygar devletler içindeki yerimizi aldığımızı" açıklaması (ÖY, 249), boğazlarla ilgili tehdidin hatırlatılması, bir zamanlar Avrupa'nın gelecek vadeden lideri olarak görülen Hitler'in İkinci Dünya Savaşı sonrası "balon gibi sönm[esi]” (ÖY, 269), benzer şekilde diğer faşist lider Mussolini'nin ölüp cesedinin Milano' da “tepe aşağı asılm[ası]” (ÖY, 276), yakınlaştığımız “Amerika'nın bize eski elbise, postal ve hurda demir vermeye hazır bulunduğunun” gazetelerde çıkması gibi tarihî gerçekler, başkarakter Aysel Dereli’nin “ölmeye yatmasına” paralel olarak okuyucu ile buluşur.

Üniversitede bir akademisyen olan kırklı yaşlardaki Aysel, aslında bir otel odasına ontolojik bir sorgulama için gitmiştir. "Yokedilişe karşı varolma yollarını arayışlar” (Ağaoğlu, 2004, s.14) hususunda düşünsel bir yolculuğa çıkan Ağaoğlu, bu ontolojik sorgulamayı sadece bireyin ontolojisine değil toplumun ontolojisine de odaklanan bir tür hatırlama ve hatırlatma eylemi olarak sunar. Aysel otel odasında iken dişarıdan "yaşasın Amerika" diye bağıran bir topluluğa bando eşlik etmekte, Aysel ise toplumsal tarih ile birlikte kendi bireysel tarihini de hatırlamaktadır. Gençlik Parkı'nda, göç ettikleri köyden ilkokul arkadaşı Aydın'la oturup bir bardak bira içtiğini, ilk defa “Avrupai kız” oluşunu, daha da “Avrupaileşip" Aydın'la el ele tutuştuğunu ve "uygar olmayı sevişi[ni]" hatırlar $(O ̈ Y, 282)$. Aysel'in uygarlık ve büyüme serüveni, Türk toplumunun uygarlık serüvenine benzer şekilde çatışmalar içermektedir. Ağaoğlu özellikle bu süreçte bireyin ve toplumun pek de farkında olmadan unuttuğu ya da bireye ve topluma kasıtlı bir şekilde unutturulan bir tarihe gönderme yapar; unutmaya karşı hafızanın bireyi ve toplumu yeniden yapılandırabileceği fikrini ortaya koyar.

Bu bağlamda, Ağaoğlu'nun üçlemeye yüklediği işlev, hatırlamayı ahlaki bir görev olarak gören ahlak felsefecilerinin görüşleri ile yakınlaşır. Bireyin ve toplumun hatırlama görevini savunan teorisyenlerden Avishai Margalit, Hafiza Etiği [The Ethics of Memory] (2002) adlı kitabında özellikle İkinci Dünya Savaşı sırasında işlenen büyük insanlık suçlarının kurbanlarını hatırlamayı insanlık için ahlaki bir görev olarak sunar. Margalit'e göre, "kötücül sistemler kendi suçlarının büyüklüğünü örtbas etmek için çabalarken ahlaki tanık onu ortaya çıkarmaya çalışır" (2002, s.165). Özellikle travma yaşayan toplumların tarihine şahitlik edecek bu ahlaki tanık, ortak hafızayı yeniden oluşturmayı amaçlayan bir faildir. Ahlaki tanığın anti-kahramanı konumundaki yalancı tanık ise doğru ve adil bir şekilde hatırlamayı engelleyen bir fail olma çabasındadır. Ölmeye Yatmak, bu bağlamda, özellikle toplumsalın alanında ahlaki bir tanıklığın 
romanıdır. Aysel'in çocukluk dönemi ile başlayan roman, "yeni bir kuşağın doğumu” ve bu doğum ile gelen "sorumluluğa" odaklanır $(O ̈ Y, 299)$. Bu kuşağın sorumluluklarından biri de toplumun yaşadığ travmalara doğru bir şekilde şahitlik etmek ve toplum için en büyük tehdit olan amneziye karşı yazarak ve hatırlatarak savaşmaktır. Ağaoğlu yazar kimliğiyle bunu amaçlarken Aysel, anlatıcı olarak toplumsal hafızayı yeniden kurma işlevini üstlenmektedir. Bu bağlamda, ahlaki bir tanık olarak Aysel, her ne koşulda olursa olsun geçmiş ve tarih ile bağların bir anda koparılmasının toplum için büyük bir travma yarattığına tanık olmuştur. Aysel'in ilkokul yıllarını hatırladığı ve romanın ilk bölümlerini oluşturan bu tanıklık, geçmişin bir anda silinmeye çalışılmasında yatan çatışmaları resmeder. Bir okul töreni için hazırlanan ilkokul çocuklarının ve onların kasabalı velilerinin yeni bir yaşam tarzıyla eski arasındaki bocalamaları ve ikilemleri, geçmiş kültürle bağları bir anda koparmaya çalışmanın parodisi olarak sunulur. Cumhuriyet ülküsü ile hareket etmeye çalışan ve Aysel'in çocukluk yıllarının önemli bir figürü olan Dündar öğretmen, çocuklar Rondo dansı yapamadığı için ya da kafalarını "ayet okur gibi”" salladığı için öfkelenmekte, onlara "camide değil”, "uygarlık kaynağı bir okulun sahnesinde" $(\ddot{O} Y, 10)$ olduklarını sabırsızlıkla hatırlatmaktadır. Oysa başöğretmenin kendisi "bir cami hocasını andırır" ve aslında o, "Latin harfleriyle adını yazmayı beceren, azıcık da değişimlere karşı yumuşak başlı davranan” eski bir hafızdır $(\ddot{O} Y, 11)$. Dündar öğretmen, "batıya bir pencere açmak adına" batı dansları yaptırarak okuldaki ilk mezuniyet müsameresini hazırlar ve eğer bunu başaramazsa "beceriksiz, yenik, ülküye sırt çevirmiş" biri sayılacağına inanır $(\ddot{O} Y, 13)$. "Medeni olmak buyrulduğu” $(\ddot{O} Y, 21)$ için Dündar öğretmen toplumun geçmişi hatta şimdisi ile ani bir şekilde bağlantısını kesmesini beklerken müsamere esnasında "eşraf ve esnaf babalar, polka ve rondo ile kirlenen namuslarını örtbas etmek için durmadan öksür[mektedir]" (ÖY, 21). Yeni bir gelecek ülküsü ile önceki kimlikleri arasında kalan toplumun bir temsilcisi olan Aysel'in babası Salim Efendi ise, yeni gelişmelerden dolayı kendini boğulur gibi hisseder; dahası, "Nemrutlaştıkça yenilik, uygarlık adına ne görürse ortalıkta, topuna birden soğukluk duymakta, hatta kin toplamakta"dır (ÖY, 56). S1klıkla bu kin, ebeveynler tarafindan yeni nesle yönlendirilecek, Ankara'da okumaya giden Aysel, tatilde kasabaya dönünce anne babasının zoru ile başını örtecek, liseyi bitirmeye yakın ise evlendirilerek okuldan ayrılmaya zorlanacaktır. Aslında Aysel'in hem Ankara' da "medeni bir âlem” olarak gördüğü "garden parti” $(O ̈ Y, 80)$ hem de kasabada yaşadığı tutsaklık Ağaoğlu tarafından bir tür dayatma olarak verilir. Hazır kalıplar ile tanımlanmaya çalışılan kimlikler, özellikle bireysel ve toplumsal tarihlerini ve geçmişlerini zorunlu bir amnezi ile yok etmeye zorlandıklarında ortaya çıkan travmalar, bireyin ve toplumun benliğine zarar verecektir. $\mathrm{Bu}$ temanın tekrarı üçlemenin son romanı Hayır...' da Tezel'in tespiti üzerinden şu şekilde verilir:

Önceden bildikleri geçersiz ilan edilmiş, bir günde bilmeleri gerekenlerle henüz tanıştırılmış bu insanlar, Salim Bey’ler, Fitnat Hanım'lar, babalarımız, analarımız yani, Meşrutiyet ile Cumhuriyet arasında sıkışıp ufalandılar. Ne sivil, ne asker bürokrat olan, ne de geçmişlerinde servet ve soyluluk bulunan bu takım, bağlandıkları son umut noktasında unutuluşa bırakıldılar. Onları bizler de unuttuk. [...] Üstelik henüz kimse, onların doğru tarihini yazmadı $(H, 48)$. 
Paul Ricoeur'ün resmî hafızayı, resmî tarihi ve ortak kimliği kontrol etmek için hafizanın "manipüle edilmesi” (2004, s.448) olarak tanımladığı toplumsal amneziyi eleştiren Ağaoğlu, bu bağlamda açıkça unutulan tarihin yeniden yazılmasını amaçlar.

Aysel karakterinin bireysel yaşamında somutlaşan bu toplumsal amnezi, onun ölmeye yattığı otel odasındaki hatırlama ritüelinde görünür kılınır. Cumhuriyete geçiş çabaları, İkinci Dünya Savaşı, soğuk savaş dönemi, ekonomik krizler ve Türkiye'de büyük toplumsal travmalar yaratan darbeler... Birey ya da toplum tarafından üstü örtülen bu toplumsal travmalar Aysel'in bireysel travmaları ile iç içe geçmiş bir şekilde anlatılırken travma sonrası iyileşme için hatırlamanın önemi ortaya çıkmaktadır. Mendeloff' un belirttiği gibi “bireyler gibi toplumlar da travma sonrası stres bozukluğu yaşayabilir. Travma geçirmiş bireyler gibi travmatik olaylarla doğrudan yüzleşmek yerine onları bastıran ulusların bu travmayı iyileştirmesi mümkün değildir" (2004, s.364). Bu bağlamda, Ölmeye Yatmak toplumsal travmaların bastırılması, yok sayılması ve onlarla yüzleşilmemesi ile ortaya çıkan toplumsal amneziye karşı bir duruştur. Roman ilerledikçe, sıklıkla ve ayrıntılı bir şekilde Türkiye tarihi ve dünya tarihine yapılan göndermeler, bireylere bugünü ve yarını doğru bir bellek ile hatırlama görevini yükler. Fakat Ağaoğlu, salt tarihî bilgiler ile bireyin dışında bir tarih ve bellek olgusundan çok, toplumsal tarihin bireysel tarih ile iç içe geçtiği bir anlatı sunarak tarihsel olgular kadar onların birey üzerinde bıraktığı duygulanımları da ortaya koyar. Örneğin, Aysel'in kız kardeşi Tezel'in İkinci Dünya Savaşı'nın altıncı yılında doğumuna paralel olarak gazetelerde “ekmek istihkakının 450 grama çıkarıldı̆̆ı” ve Ankara Valiliğinin de şeker dağıtımıyla ilgili olarak gazetelere resmî ilan verdiği belirtilir: "1-Değişmez ve dar gelirlilere ocak-şubat-mart ayları için şeker dağıtımına ayın 15'inden itibaren başlanacaktır. 2-Dağıtma, Memurlar Kooperatifi Şirketi tarafından yapılacaktır" (ÖY, 233). Bu sırada, komünizme karşı milliyetçi bir duruş geliştiren Aysel'in abisi İlhan, sıkıyönetim mahkemelerindeki duruşmalara protesto için gitmekte, "baskında yakalananların içinde bir kez daha kendini dar kurtarıp anasının loğusa döşeğine sığınmışken" karlı bir başkent sabahı içeriden Tezel'in durmayan ağlayışları gelmekte ve "Aysel X'i, Y'yi ve Z'yi belirsiz bir denklemi vazgeçmeksizin çözmeye çalış[maktadır]” (ÖY, 234). Bireysel ve toplumsal tarihin örüldüğü bir başka hatırada ise Hiroşima’ya atılan bombalarla ortaya çıkan iniltiler ile eşzamanlı olarak Aysel'in evlenmek istemediği için yediği dayakla duyulan iniltiler bir arada verilir $(\ddot{O} Y, 335)$.

Aysel, ölmeye yattığı bu otel odasında toplumsal tarih ile örülmüş bireysel tarihini hafizasına dönerek yeniden kurmaktadır. Bu süreç ise, amneziye karşı duran fakat sadece büyük tarihsel olgular değil bireylerin minör tarihlerini da anlatan birbirleriyle bağdaşık bir süreçtir. Bu bakımdan roman sadece Aysel'in ve ailesinin değil onun hayatına dokunan birçok karakterin büyük tarihsel anlatılar ile birlikte ilerleyen minör tarihlerini içerir. Avrupa'da savaş son bulmak üzere ve Ankara'da dar ve sabit gelirli ailelere ekmek karneleri dağıtılmakta iken Aysel'in ileride öğrencisi olacak Engin'in, yine bir gazete kupürüne yansıyan bireysel tarihi verilir. Karadeniz kırsalındaki bir kasabanın kaymakamı, çocuklarına bakamayan aileleri büyük bir ülkü ile ikna edip bu çocukları evlatlık verme girişiminde bulunmaktadır ve Engin'i “23 Nisan Bayramı'nda, Cumhuriyet Alanı'nda vereceği söylev için iyi bir örnek” $(\ddot{O} Y, 258)$ olarak görür. 
Oysa, kocası ile kaymakamın yaptığ 1 iş birliğini bozan Engin'in annesi onu evlatlık vermemekte diretir ve bu nedenle kendisini “altı çocuğu ve bir ineğiyle Adapazarı'nın batak bir köşesinde” terk eden kocasını beklemekten bir süre sonra vazgeçer (ÖY, 262). Bu durumda, Engin'in sınıfsal sisteme karşı duran bir devrimci olmasının nedeni sadece mevcut tarihsel konjonktür ile değil onun bireysel tarihi ile bağlantılı olarak verilir. Böylelikle romanın anlatıcısı Aysel üzerinden hem bireysel hem de toplumsal tarihi ve hafizayı yeniden yazan Ağaoğlu, unutmaya karşı geçmişin sorumluluğunu üstlenmeyi ahlaki bir görev olarak sunar.

Blustein, kişinin geçmişi görmezden gelmemesini, bastırmamasını, tahrif etmemesini ve kendini kandıracak şekilde inkâr etmemesini savunur (2008, s.62). Ağaoğlu'nun üçlemesi de bu açıdan unutmanın tehlikelerine karşı doğru bir şekilde hatırlamanın gerekliliğini ortaya koyar. Volf’un "yalancı tanık” olarak kavramsallaştırdığı (2006, s.64) olgunun karşıtı olan, Margalit' in "ahlaki tanığı” Aysel karakterinde somut hâle gelir. Margalit ahlaki tanığı, ortak hafızanın bir faili olarak görür ve ancak kişilerin paylaştığı ortak anılar sayesinde ortak bir "biz” hissi ve fikri ile "yakın bir ilişki” kurulabileceğini vurgular (2002, s.93-96). Bu açıdan Margalit Hafiza Etiği [The Ethics of Memory] (2002) adlı kitabında tarih ve hafizayı kıyaslarken özellikle ortak hafıza bağlamında, tarihi soğuk ve ruhsuz, hafızayı ise canlı olarak tanımlar. Hafızanın tarihsel bir olgudan farkı, onun kişi için geçmiş ile şu an arasında bir bağ kurabilme özelliğidir. Tek başına tarih sadece geçmişin temsili iken hafıza geçmişi, şimdiyi ve geleceği bir arada tutar. Bu bağlamda, Ölmeye Yatmak romanı ilerledikçe hem soğuk tarihsel anlatı kronolojik olarak akmaya devam eder hem de karakterleri birbirlerine ve okuyucuya bağlayan, onlara "biz" hissi veren bir hafıza yazımı kurulur. Tarihsel anlatıda Avrupa' da savaş bitmiş, fakat bir yandan Suriye'de bir yandan Japonya'da bir başka savaş tüm hızıyla devam etmektedir; Fransızlar Şam'ı dehşetli bir top ateşine tutmakta, Churchill Fransız kuvvetlerine ateşkes emri verilmesini söylemektedir; bu sırada TBMM'de toprak kanunu ve çok partili döneme geçiş görüşülmektedir (ÖY, 300-301). Fakat Ağaoğlu, salt tarihsel bir anlatı ve hatırlama değil bireylerin ortak bir "biz" oluşturacağı ve böylece ortak bir hafıza geliştirebileceği bir anlatı sunmaktadır. Bu bağlamda, bir zamanlar kasabada ilkokul öğrencileri olan karakterlerin genç yetişkinlik zamanları tarihsel birer prototip olarak anlatıya dâhil edilir.

Romanın ismi ile müsemma karakteri Aydın, Kurtuluş Savaşı'nda Ulu Önder'in yanında olmuş kasaba kaymakamının daha sonra Galatasaray Lisesine giden oğludur. Batılı bir medeniyete özenen Aydın, bir süre sonra kendi babasını bile yeterince "medeni” görmez, Alman yengesinin yanında onun basit ve köylü durduğunu düşünür $(O ̈ Y, 127)$. Aydın’ın "Hatıralarımı ve Hislerimi Yazdığım Defterdir" dediği $(\ddot{O} Y, 167)$ hatıratı ile beslenen bu bireysel tarih, ortak tarihin bireyi nasıl şekillendirdiğini göstermektedir. Aydın, İstanbul'da babası bir gazete patronu olan ve köşkte oturan arkadaşı Metin'in hayatına özene dursun, Ankara'daki okulundaki bir başka arkadaşı Namık, önce zengin aile çocuklarına yakınlaşmakta, daha sonra ise bu kişilere karşı bir öfke geliştirmektedir. Köylü sınıfı bir aileden gelen Ali ise, Dündar öğretmenin tüm çabaları ile Ankara'da bir erkek sanat okuluna yazdırılmış, hem zor şartlar altında bir otelde karın tokluğuna çalışmakta hem de daha sonra ona Ankara Radyosu'nda elektrikçi olarak bir iş bulmasını sağlayacak okuluna gitmektedir. İçinde bulunduğu durumdan 
dolayı “Türklüğünü” ve Türklüğe yakışır biri olup olmadığını sorgulayan Ali’nin bir yapının üzerinde asılı bir dövizde yazan "Tarihi Yeniden Yapan El Seni de Yapıyor. Ne Mutlu Sana!" $(O ̈ Y, 103)$ cümlesini görmesi ile tarihin bireyin kimliğini oluşturmadaki önemi ironik bir şekilde verilir. Ertürk ise yine tarihin yarattığı asker çocuk tipini temsil eden bir karakter olarak, "sert adımlarla yürümeyi, sert bakmayı ve sert yatakta yatmayı"; "kız adı anmamayı, ağlamamayı, anasına değil de babasına mektup yazmayı” öğrenen bir askerî lise öğrencisidir $(O ̈ Y, 140)$.

Ortak bir tarihin ve bu tarih içinde şekillenen bireylerin ilk gençlikten yetişkinlik sürecine geçişlerini anlatan Ölmeye Yatmak romanı, bu gençlerin tarihsel konjonktürde yetişkinliğe nasıl evrildiklerine okuyucuyu tanık eder. Galatasaraylı Aydın, hayali olan Dış İşleri'nden istifa edip İstanbul' da sol yayınlar basan bir yayın evi kurarak "bir değişim kavgasına yayınlarıyla katıl[may1]" amaçlar $(\ddot{O} Y, 285)$. İlk gençlik yıllarında ülkü sahibi ve doğrunun yanında olmaya çalışan fakat sonra "[p]aranın tek otorite olacağı bir toplum düzenine doğru hızla yol alındığını sezen" $(O ̈ Y, 366)$ İlhan, zengin milletvekillerine hizmet eden inşaat patronu bir avukat olmuştur. Ertürk, çocukluk arkadaşı Ali’yi komünist olmakla suçlayan bir subay olurken Ali edebiyattan hoşlanan bir işçi sınıfı bireyi olarak tasvir edilir. Üçlemenin genelinde bu bireysel tarihlerin ortak noktası olan Aysel ile karakterlerin tarihi ve hafizaları üzerinden okuyucuya bir hafıza ve tarih yazımı sunulur.

Yıllarca uğruna savaştığı değişime karşı inancı sarsılmış olan Doçent Aysel, roman boyunca bir otel odasında, verdiği savaşa devam etmek ile her şeyi bırakıp ölmek arasında (ÖY, 205) gidip gelmekte, roman anlatı zamanını kapsayan bu iki saat Aysel'in geçmiş sorgulamalarını içermektedir. Aslında Aysel'in savaşı, unutmaya karşı hatırlama arasında gidip gelen bir mücadeledir. Bireysel hafıza ile toplumsal hafızanın karıştı̆ğ bir deliryum hâlini anlatan bu iki saatlik süreç, koca bir Cumhuriyet tarihinin çalkantılarını içinde barındırırken karakterin bilinç akışına toplumsal bir bilinç akışı eşlik eder. "Kadınlık", "uygarlık”, "batıcı", "geri kalmışçı" gibi kimlikler arasında boğulan Aysel, aslında bu otel odasında ilkokul yıllarından başlayarak bireysel tarihini ve hafızasını kurmaktadır. Kendi bilinçdışı ile ortak bilinçdışının kesiştiği noktalar, unutmaya karşı alınan bir tavır olarak görülmelidir. Maurice Halbwachs, Ortak Hafıza Üzerine [On Collective Memory] (1992) adlı kitabında, hafızayı ortak (kolektif) bir oluşum olarak tanımlar. Bu bağlamda, ortak hafıza bireysel hafızaları ve kimlikleri şekillendirmektedir. Aysel'in “yeşil yüzlü profesörler” rüyasındaki kaygısı olan ülkeyi nasıl kalkındıracağının formülünü bulamaması, aslında ülkenin geçtiği buhranların bireyin hafızasında ve kimliğinde yarattığı travmayı gösterir. Aysel bir yandan bireysel hatıralarına dönerken (kendisi mülkiye üçüncü sınıfta, kocası Ömer de aynı fakültede ünlü bir profesörün genç asistanı iken Fransızca bildikleri, Beethoven dinledikleri için nasıl da uygarlık seviyesine ulaştığını ve "Atatürk başımızın üstünden bize bakıyor. Göğsü kabarıyor.” (ÖY, 349) diye düşündüğünü hatırlar) bir yandan da tekrar toplumsal tarihe geçerek ülkede ve dünyada vuku bulan kaosu hatırlar:

Birleşmiş Milletler'de barış çalışmaları -İran'da olaylar- Hindistan'da bağımsızlık hareketleri - Mısır'ın bağımsızlığı - Cava Müslümanları - Çin Hindistan'ında savaşlar - Yeni bir Arap devleti kurulması için hareketler - İran ve Rus antlaşması - 
Almanya sorunu - İstanbul ve Çanakkale Boğazları sorunu - Türkiye’de komünizm ürpertileri - Komünizm, faşizm çarpışması - Tan olayı - İstanbul'da sıkıyönetim, vb ... (ÖY, 357).

Aysel otel odasında tüm bunları hatırlarken aslında zihninde "yeni boşluklar" oluşmakta; özgürlük, eşitlik, demokrasi, cumhuriyet gibi kavramlarla "beyni oyulmakta"dır $(O ̈ Y, 381,383)$.

A ğaoğlu, tarihsel bir anlatı ile bu zihinsel sorgulamanın okuyucunun zihninde de yer edinmesini amaçlamıştır. Bu bağlamda, Aysel'in ölmeye yatma ritüeli aslında geçmişi ve anıları hatırlayarak hafızayı yineleme ile geçmişe yeniden kök salma çabası olarak okunmalıdır. Tarih ile hatırlama arasında fark olduğunu savunan Margalit, hatırlama görevinin değerinin tarihin yaptığı gibi zafer kazananların değil acı çekenlerin hatırlanması olduğunu savunur (2002, s.10). Ağaoğlu da bir tarih yazını içinde kahramanları değil, ortak hafızanın genellikle unutturmaya çalıştığı acı çekenleri resmeder. Böylece hem Ağaoğlu ve başkahramanı Aysel hem de okuyucu kolektif hafızanın bir faili, "kötülük ve onun ürettiği acının birleşimine" (Margalit, 2002, s.148) zihnini kapamayan ahlaki bir tanıktır. Bireysel ve toplumsal amneziye karşı hatırlamanın ahlaki yönü romanın en son sayfalarına kadar devam eder. Hem ülke tarihi hem de kişiler hakkında güncel gelişmelerden bahsederek sonlanan romana Aysel'in beş yaşındaki bir anısı eşlik etmektedir. "Küçüktüm ufacıktım top oynadım acıktım” çağında iken Aysel, güzel bir çiçeğe dokunduğunu zannederek zehirli bir hayvana dokunduğu için parmağ1 kesilmiş, zehir akıtılmıştır $(O ̈ Y, 385)$. Aslında Aysel'in tıpkı o zamanki gibi şimdi ağladığı şey "umulmadık bir anda yanılmış olmanın acısı", "bundaki dayanılmazlık”tır $(\ddot{O} Y, 386)$. Tüm yetişkinlik tecrübesini temsil eden bu çocukluk anısında somutlaşan ulusal bir tarihi hatırlamak ise özellikle Türk okuyucunun benzer bir his duymasına neden olur. Yine de tarihe ve hafizaya dönüş, Aysel'in yaşama yeniden kök salmasına zemin hazırlamıştır: "Duştan çıkıyorum. Bir saksıyı çatlatıp ağır ağır toprağa yayıldığımı duyuyorum. Ama toprağın beni kavrayıp kavramayacağını bilmiyorum" (ÖY, 393) diyen Aysel, okuyucuya da benzer bir yeniden kök salmayı salık verir gibidir. Aysel, otel odasına geldiğinde "ölmeyi bile beceremeyecek kadar geç kalınmış olduğunu” düşünmüştür. "Ölmek nedir? Ölmek, yaşamış olduğunu bilmeyi gerektiriyor." (ÖY, 282) sözleriyle yaptığı zihinsel sorgulama, onun aslında “ölebilen tek şeyin zaman" (ÖY, 283) olduğunu anlamasına neden olur. Aslında bireysel ve toplumsal hatıralar ve hafıza ne kadar öldürülmeye çalışılsa da bu sorgulamada gün yüzüne çıkanlar hem Aysel'e hem de okuyucuya yeni bir pencere açmıştır. Bu bağlamda Ağaoğlu, hafızanın "canlı tutulması" gerekliliğine (Margalit, 2002, s.58) vurgu yapan hafıza etiği teorisyenlerine oldukça yaklaşır ve hem bireysel hem toplumsal amneziye karşı hatırlamanın ahlaki yanını ortaya koyar.

\section{Unutmaya Sığınan Birey ve Toplumun Trajedisi}

Ağaoğlu'nun üçlemesinin ilk romanı olan Ölmeye Yatmak nasıl bireysel ve toplumsal amneziye karşı bir hatırlama ve hatırlatma ritüeli ise, Bir Düğün Gecesi de genelde Tezel ve Ömer'in, özelde ise diğer minör karakterlerin yaşamlarında nasıl bir unutma ritüeline saplandıklarını, fakat bir düğün gecesinde bastırılanın ve unutulmaya çalışanın Freud'un 
tekinsizi misali geri döndüğünü resmeder. Bu bağlamda Bir Düğün Gecesi, geçmişlerini unutmaya sığınan karakterlerin içinde bulundukları açmazın bir anlatısıdır. Her ne kadar bireysel tarih ile toplumsal tarih yine iç içe geçmiş olsa da bu romanda karakterlerin bireysel tarihi ve hafızası ön plana çıkar. 1930'larda ilkokul çocukları olan karakterler artık yetişkindir ve toplumun farklı kesimlerinden insan manzaraları sunarlar. Özellikle yeni bir sınıfsal sistemin kurulduğu bu dönemde, "dün tarhana kararken bugün pokere oturan”, “dün köylüye urgan, kına satarken bugün ansızın yedek parça, motor ve kaçak otomobil lastiğì" satan kadın ve erkeklerden oluşan bambaşka bir toplumsal düzen vardır $(B D G, 12)$. Bir düğün gecesinde bir araya gelen bu hibrit topluluk "çiğköfte ile Ankara tavasını gümüş çatallar ve köpüklü şarap eşliğinde yiyen bir kalabalık” ( $B D G, 20)$ olarak tasvir edilir. Bu kalabalıkta her karakterin iç sesi kendi tarihini yansıtmaktadır.

Tezel'in ilk iç sesi; hatırlamak ve unutmak üzerine zihninden geçenler; fikraları unutmamak isteyen kalabalığı düşünmesi romanın açılışında hatırlamak ve unutmak kavramlarını gündeme getirir. Tezel, kendisi unutmak için çaba sarf ederken insanların hatırlama çabalarını anlamsız bulur: "Deftere geçirilerek anımsanan şeylerden bir hayır gelirmiş gibi. Hele bu anımsamak, unutmamak istekleri yok mu, iyice canımı sıkıyor. [...] Anımsamak, gözden geçirmek, derlenip toparlanmayı çağırır. Demek bunlar hâlâ tutunacak bir yer, ayaklarına basacak bir toprak istiyorlar!" $(B D G, 26)$. Tezel insanların anımsayarak, hatırlayarak ben olmalarını anlamsız bulur; onun çabası unutmaktır. Zoraki geldiği, abisi İlhan'ın kızı Ayşen'in bu düğünü onu geçmişinin derinliklerine götüren bir yolculuğu başlatacaktır. İstanbul'dan Ankara'ya giderken otobüste başlayan bu hafiza yolculuğuna ise inatla direnir: "Burnuma bizim Küçükesat'taki evin kokusu geliyor. Aman, tıka burnunu. Bir de eski, iyice eski kokulara dönersek işimiz var!" $(B D G, 31)$ Tezel için açıkça unutmak değil hatırlamak acı verir; ailesini her ziyaretinde ailesinden bir şey eksilmiş gibi hisseder: "Eski küçük kırgınlıklar bile silineceğine azmanlaştı." diye düşünür $(B D G, 72)$. Tezel geçmişten kurtulmaya çalışan bir karakterdir; sürekli hortlayan iç sesini dinlemek istemez ve hatırlamaya karşı büyük bir öfke duyar: "Bunamışlar örneği, hep geriyi yaşayan...” $(B D G, 84)$ diyerek de hatırladıkça kendini suçlar. Aslında bir tür iç hesaplaşmadan kaçan Tezel; yaşamını, sosyalistliğini, anneliğini, evlatlığını, kardeşliğini sorgulamaktan kaçmaktadır. Babası deri tüccarı, kendisi “devrim tüccarı” $(B D G, 67)$ olan kocası Oktay'ın arkadaşları ile kotrasında sosyalizm tartışmasını, kendi çocuklarıyla bile ilgilenmezken ülkeyi kurtarmaya çalışmalarını, kendilerini "kaynana ile kayınbabaya besleterek profesyonel devrimcilik yapmaları”'nı $(B D G, 61)$ istemeyerek de olsa düşünür. Tezel'in unutmaya çalıştığı fakat unutamadığı en önemli olay ise açtığı resim sergisinde bir aktivistin ona tokat atması ve bu tokadın onu geçmişte abisi İlhan'ın attığı tokada götürmesidir. Ankara'ya yaptığı yolculuk, Tezel'in unutmak istediklerini sinsice su yüzüne çıkarır: "Yahu, unutsana artık. Kaç yıl geçmiş. Hatırası kıt koca karılar gibi dönüp dolaşıp aynı noktaya takılıyorsun. [...] Bu oyunu şu otobüs oynuyor bana. [...] Geçmişe, Ankara'mıza doğru yapılan bu yolculuk oynuyor..." (BDG, 57).

Özellikle hafıza etiği alanında hatırlamanın ahlaki bir görev olduğunu savunan teorisyenlerin yanı sıra unutmayı da ahlaki bir sorumluluk olarak görenler vardır. Örneğin Nietzsche, unutmayı savunmuş, satirik bir şekilde mutluluğun ancak "unutmak" ile geleceğine inanmıştır; 
unutmayı "olumlu bir kuvve" olarak görür ve "unutmak olmaksızın olumlu şeylerin tecrübe edilemeyeceğini” savunur (1989, s.57, 58). Benzer şekilde Fransız antropolog Marc Augé Unutma [Oblivion] (2004) adlı kitabında unutmanın bireyin ve topluluğun iyiliği için gerekli olduğunu, ancak unutma ile hafızanın anlamlı bir şekil alacağını savunur. David Rieff, Unutmaya Övgü [In Praise of Forgetting] adlı kitabında ise geçmiş acıları hatırlamanın bireye ya da topluma bir fayda sağlamayacağını, özellikle geçmişte yaşanan acımasızlıkların öfke ve nefreti besleyeceğini, "unutmak geçmişe karşı bir haksızlık iken hatırlama şimdiye karşı bir haksızlıktır” diyerek savunur (2016, s.108). Bu bağlamda, Ağaoğlu'nun Tezel'e bir düğün gecesine giderkenki yolculuğu ile başlayan iç hesaplaşmasında unutma taraftarı bir bakış açısı giydirmesi, Tezel'in unutmanın da bir görev ya da gereklilik olabileceği düşüncesiyle örtüşür. Bir düğün gecesinde özellikle Tezel'in unutmak için sürekli içmesi ve Ömer'e "İntihar etmeyeceksek içelim bari!" demesi, onun unutmaya tutunma çabasını gösterir. Unutmanın arzulandığının fakat başarılamadığının farkında olan Ömer ise Tezel'in yaşamın tüm ağırlığını hatırlatan o tokadı asla unutmayacağını düşünürken kendi kendine şunu sorar: "Unuttum dediklerimiz değil mi, en unutulmaz olanı?” $(B D G, 108)$ Aslında Ömer de tıpkı Tezel gibi birçok şeyi unutmak istemekte, Tezel'e bir iç haykırış ile "Bana beni unuttur" $(B D G, 69)$ demektedir. Oysa Ömer'in ne kadar çabalasa da hiçbir şeyi unutmadığı görülür. Ömer, Aysel'in kendisine öğrencisi Engin ile birlikte olduğunu söylemesini; düğünün gelini ve Aysel'in yeğeni Ayşen'e olan ilgisini; Aysel ona "açık olduğu denli”, onun Aysel'e "açık olmayı" göze alamamasını (BDG 237$)$; tutuklu iken hapisten çıkmasının devrimciler arasında şüphe ile karşılanmasını; düğünde karşılaştığı ve bir milletvekili kızı ile evlenmiş olan eski öğrencisi Tuncer'in bir zamanlar Ömer'i Karl Marx’1 anlatıp dersleri boykot etmeyerek "somut eyleme” $(B D G, 170)$ geçmediği için "ilerici aydın” olmamakla suçlamış olmasını $(B D G, 192)$ unutamamaktadır.

Tezel bilinçli bir şekilde Ömer ise farkında olmadan unutmaya sığınmış, fakat bu düğün gecesinde sadece onların değil diğer karakterlerin de tüm anıları ve duygulanımları geri gelmiştir. Bu bağlamda Ağaoğlu unutmayı, acıya karşı bir savunma mekanizması olarak gören hafıza etiği kuramcılarının aksine, bireyin kimliğini ve tarihini oluşturmaya engel olan bir tür sahte mutluluk olarak yansıtır. Bir Düğün Gecesi’ndeki göndermelerle birlikte düşünüldüğünde Ölmeye Yatmak, Aysel'in ancak hatırlayarak ve geçmişle yüzleşerek yaşama tutunabildiğini gösterir. Oysa Tezel ve Ömer hafızalarında diplere süpürdükleri hatıralar ile hâlâ cedelleşmektedir. Aysel, “ölmeye yatmak” ya da Ömer'i ve Engin'i kapsayan tüm geçmişi hatırlayıp onunla yüzleşme ritüelini Ömer’e şöyle anlatmıştır:

Yüreğini oyup önüne koymuş. Beynini çıkarıp eline almış. Görebildiği bütün kötü urları, kılçıkları, tozları, geçmişin biriktirdiği, tarihinin yığglı̆̆ı nice hastalıklı hücre varsa hepsini, elbet bir gözün görebildiği, bir mikroskobun seçebildiği oranda tek tek cımbızla ayıklamış. Buna dayanan, yalnızlığa en iyi dayanır. Kesip biçtikleri, ayıklayıp attıkları arasında değilsem, birlikteliğimizin sürmesinden onur duyacağımı söylemiştim ona $(B D G, 114)$.

Ömer'in aktarımı ile öğrendiğimiz Aysel'in tecrübesine Ömer her ne kadar büyük bir 
anlayış göstermiş gibi dursa da bir dügüun gecesinde Ömer'in aslında hiçbir şeyi unutmamış ve affetmemiş olduğu, sadece geçmişini bastırdığı görülmektedir. Sürekli Aysel'in düğüne gelmemesinden yakınan kayınvalidesi Fitnat Hanım'a "Bırakın şu Aysel lafını artık!" diye çıkışması, onun bastırmış olduğu öfkesini açığa çıkarır $(B D G, 350)$. Benzer şekilde, düğünden ayrılırken ona eski öğrencisi Tuncer "gidiyor musunuz hocam" diye sorduğunda "Aslında, ne yapsam, ne etsem onun, kürsümün karşısına geçip 'İnin aşağı, inin aşağı!.. Bizimle yürüyün!'lerini unutamıyorum [italik bize ait]” $(B D G, 359)$ diye düşünür.

Ömer ve Tezel, Aysel'in evinde bir anarşist sakladığı haberiyle düğünden apar topar ayrılırken Tezel, Ömer'in artık öğüt verici olmadığını, Ömer ise Tezel'in intiharın ya da sessiz bir ölümün değil "yaşama dalmış çıldırının” eşiğinde olduğunu fark eder; burnunda kömür ve barut kokusu, kulaklarında Ankara misket havası ve içindeki “yara”yla düğünden ayrılır ( $B D G$, 376). Bu farkındalık, unutmaya çalışmanın beyhudeliğini ve içindeki yara ile yaşamak gerektiğini fark eden Ömer'in unutmayı artık bir çözüm olarak görmediğini gösterir. Ağaoğlu böylece, Tezel'in ve Ömer' in hafızalarından her şeyi silmeye çalışan yaklaşımlarının yanlışlığına vurgu yapar. Bu noktada, Ağaoğlu'nun ortaya koyduğu fikir, hafiza teorisyenlerinden Ricoeur'ün "derin unutma"ya (profound forgetting) karşı, "geri getirilebilen” (back up forgetting) unutma olarak savunduğu görüşü hatırlatır. Buna göre, birey ve toplum "tüm izleri silerek” unutmak yerine, geri getirilmesine izin verilen "yedeklenmiş bir tür unutma” yı benimsemelidir (2004, s.414). Tezel ve Ömer, yaşamlarında ilkini yapmaya çalıştıkları için bunu amaçlayan herkes gibi bir buhranın içindedirler. Ömer ise ancak unutmaya çalışmanın anlamsızlığını fark edip, hafızasında yolculuk etmeyi göze alınca bunun ayırdına varır. Ömer, "Bir düğünde hemen herkes, bir ucundan eski nikah defterlerini kurcalar" $(B D G, 114)$ diye düşünürken Ağaoğlu tüm karakterlerin nasıl da hafızalarını kurcaladığını bilinç akışı ve iç monolog teknikleri ile okuyucuya sunmaktadır. Karakterlerin bilinç akışı özellikle toplumsal sınıfların nasıl ortaya çıktığıyla paralel olarak hem bireysel hem de toplumsal bir hafıza yolculuğudur: Ertürk'ün ablası Amerika'daki Ayten halanın Eytın hala olması; İlhan'ın, kızı Ayşen'i devrimci bir gruba karıştı̆̆ı için Hayrettin'in oğlu ile evlendirirken karısı Müjgan'ın hem buna hem de İlhan'ın reklamcı İnci ile "ortasında parlak çıkar yıldızı oturmakta" olan ilişkisine $(B D G, 129)$ göz yumması; sadece "mal mülk üzerine kurulan" $(B D G, 289)$ ailesinden, "bir merhabasızlıktan, bir sevgisizlikten, bir bakıştan” açlık duyan (BDG, 301) Ayşen'in, babası İlhan'ın zenginliğine öfkelenen devrimci gruba yakınlaşmak için gözaltına bile alınmayı göze alması; Aysel'in annesi Fitnat Hanım'ın Ayten ve kardeşi Nuriye'nin kasabada şalvarlı hâllerinden nasıl da asker eşi olmaya terfi ettiklerini ve "avurtları göçmüş bu subaylar"1n "bugün koskoca paşalar" ( $B D G$, 153) olmalarını düşünmesi; bu paşalardan Hayrettin ile kızını evlendiren İlhan’ın, kardeşi Aysel ile seçtikleri yolların nasıl da farklı olduğu ve bu yolda başarı ve doğrunun artık para ve güç ile geldiği $(B D G, 161)$ farklı ama kesişen hafızalar üzerinden okunmaktadır.

Unutmaya tutunan karakterlerin bir anlamda fışkıran hafızaları, Ağaoğlu'nun bu romanında özellikle bireysel hatırlamayı ahlaki bir eylem olarak görmesiyle bağlantılıdır. Hafıza teorisyenlerinden Blustein, hatırlama görevini sadece büyük suçlar ve toplumsal yaralanmalarla değil bireysel tarihi hatırlamanın önemi ile de ilişkilendirerek hatırlamanın "bireyselleştirilmiş 
bir görev" olduğunu söyler (2017, s.353). Bu noktada, bir düğün gecesinde bu görevi bilinçli olarak ya da bilinçdışı saiklerle yerine getirmeye çalışan karakterlerin sırasıyla ağlaması, hafızanın yenilenmesi ile ortaya çıkan duygu boşalımı ve geçmişi için yas tutabilenlerin geçmişini affetmeye adım atabileceği fikrini verir. Ağaoğlu'nun hem bireyin hem toplumun unutma çabasının ancak bir trajedi yaratacağı, unutmanın bireyin kendine ve topluma adil davranmaması anlamına geldiği görüşü üçlemenin son romanı Hayır ... ile özellikle ön plana çıkacak; hatırlamanın birey olmadaki rolü, kişinin hem kendine hem ötekine adil olması için ortak bir tarihi paylaşmak gerektiği ve bunun için geçmişteki hatıraların yasını tutup hatıraları ve kişinin kendisini özgür bırakması gerekliliği fikri verilecektir.

\section{"Hayır, delirmedim. Çünkü hala hatırlıyorum."}

Ağaoğlu'nun üçlemesinin son romanı olan Hayır ... bireyi baskılayan, kısıtlayan; toplumun, kendi tarihini ve geleceğini görmesini engelleyen; "tarihle bağı koparan” (Alver, 2013, s.10) tüm ketlere karşı "hayır" demeyi savunan bir anlatıdır. Hafıza bağlamında da unutmaya ya da unutturulmaya karşı güçlü bir "hayır", bu romanda hem başkahraman Aysel hem de Engin, Cemil, Tezel gibi diğer karakterler üzerinden okunmaktadır. Bireysel ve toplumsal travmaları, kayıpları ve acıları hatırlamanın otantik bir kimlik kurmadaki gerekliliği bu son anlatıda yeniden dile getirilirken öncelikle bu hatırlama kişiye ve topluma karşı adil olmak gerekliliği olarak sunulur.

Blustein'a göre kimlik ile bağlantılı olan yükümlülükler, kişinin kimliğinin kurucu unsurlarıyla içsel olarak ilgili olan geçmişini tüm yönleriyle hatırlama yükümlülüklerini içerir ve geçmişin travma ve acılarını hatırlama, kimliğe yapılan saldırılara karşı bir savunma mekanizması oluşturur (2008, s.49). Hafızayı şekillendiren ve hafıza ile şekillenen (Blustein, 2008, s.2) bireysel ve ortak kimlik, ancak hafıza ya da hatırlama ile geçerlilik kazanmaktadır. $\mathrm{Bu}$ noktada üçlemenin son romanı, delirerek unutan ya da baskılayarak unutmaya çalışan zihinler ve bu nedenle kimlik kazanamayan bireyler üzerine yeni bir tartışma sunar. Artık akademiden kovulan değil ödüllerle takdir edilen Profesör Aysel, darbelerle geride kalmış buhranlı bir tarihin tanıklarındandır. "Aydın İntiharları ve Geleceğin Başkaldırısı" $(H, 11)$ başlıklı bir çalışma üzerine kafa yorarken iç monologlarından sıklıkla her şeyi unutmaya çalıştığı görülmektedir. "Kapı çalınıyor. Kapıcıdır. Ona bugün hiçbir şey gerekmediği söylenecek. Hayır, süt de istemez. Teşekkür ederim: Unutulmak istiyordum. Geçmişi kendimin de unutmasını, en çok bunu istiyordum" $(H, 104)$. Geçmişsiz ve hatırasız olmaya sığınan Aysel, bu nedenle adını vermediği kentte konakladığı otelin, Karin'in evinde hiçbir şeyi “anımsatmaksızın” duran posterlerin ve fotoğrafların anlık huzuruna kapılır. Fakat bu huzur sorunsaldır. Aysel, geçmişi anımsamadığı zaman "geleceği tasarlamak da güçleşiyor, hemen hemen olanaksızlaşıyor" $(H, 104)$ diye düşünerek geçmişi unutmanın gelecek tahayyülünden de yoksun bıraktığını kavrar. Yine de Aysel, zihnini baskılamayı acıyı azaltan bir tür savunma mekanizması olarak görmekten kendini alamaz. Akademiden atıldığı dönemlerde nelerle suçlandığını hatırladığında acı çekmektedir; zihninde bu suçlamalar yankılanır: "Komünist", "yatakçı", "vatan haini”" $(H$, 141-42) ... Sırf bu nedenle hayalindeki plaket töreninde unutmaya sığınmaktadır: "Değerli 
üyeler, değerli meslektaşlarım! Hiçbir şey hatırlamıyorum. Çok mutluyum" $(H, 152)$. Oysa bu reddediş, Ricoeur'ün (2002, s.7) "hafızanın hastalıkları, temelde kimliğin hastalıklarıdır” dediği durumla eşdeğerdir ve öncelikle kişinin kendi kimliğine karşı adil olmamasıyla bağlantılıdır. Ricoeur'ün hafıza etiğinde üzerinde durduğu önemli bir nokta, hatırlama görevinin "adalet" erdemi ile ilişkili olmasıdır. Ona göre, hafızanın iyi yönde kullanılması ya da suistimal edilmesi kendine ya da topluma adil olmak ya da olmamak ile bağlantılıdır (2004, s.87, 89). Ağaoğlu'nun, Aysel karakteri üzerinden hatırlama ya da unutma arzuları arasında gidip gelmesi de bu tür bir adalet sorgulamasını andırır. Bu iç sorgulama, Aysel'in iç içe geçmiş ödül törenindeki hayali konuşmasına ve kuaföründeki iç monoloğuna şu şekilde yansır:

Hiçbir şey hatırlamıyorum değerli konuklar, hiçbir şey. Mutluyum. Sakin sakin Aydın İntiharları ve Geleceğin Başkaldırısı incelememi sürdürüyorum. Toplu aydın intiharları olacağa benziyor.

Ama bu çok tehlikeli.

Evet ama unutulabilir. Hayatı sakin sakin sürdürebilmenin anlamı da başka nedir? Hiçbir şey hatırlamıyorum Bahattin Bey, hiç!

Boyayı iyi sürün. Yıllar, pardon, aklar kapansın (H, 153-154).

Ricoeur'ün bahsettiği ve Ağaoğlu'nun tartışmaya açtığı sorun, yani hafızanın suiistimal edilmesi ya da gerçekliği manipüle etmek için kullanılması aslında adaletsizlik içerir ve kimliğe karşı bir tehdittir. Bu durumda çözüm, unutmak değil özellikle bir haksızlığı ya da kötülüğü hatırlayarak ona karşı savaşmak (Volf, 2006, s.11), böylece kendine ve başkasına karşı adil kalabilmek ve sonuç olarak bir kimlik kurmak olacaktır. Öyle ki Aysel'in tüm baskılamasına rağmen bilinç yüzeyine çıkan anıları, onun "yılan gömleği değiştirir gibi ölmeye yattığı" ( $H$, 286) ilk anlatıda olduğu gibi bireysel ve ortak tarih ile yüzleşmesini gerektirmiştir. Bu nedenle, asistanı Alev'e ölmeye yatmak tecrübesini anlattığı sohbet, "tarihi yapma konusunda kişilerin kendileriyle ne oranda yüzleşip yüzleşmediklerinden konuşmak" olarak tanımlanır $(H, 286)$. Aysel'in üçleme boyunca en önemli tecrübesi, bu bağlamda, bireyin kişisel ve ortak tarihi ile yüzleşmesidir.

Hatırlamak ve unutmak arasında gidip gelen diğer bir karakter, üçlemenin son romanında kişisel tarihi hakkında daha çok bilgi edindiğimiz, Aysel'in eski öğrencisi Engin'dir. İronik bir şekilde, bu romanda "karşıt ideolojide iki kişi, cellat ve kurban, aynı statü altında birbiriyle karşılaşır” (Ağaoğlu, 1993, s.188). Hem geçmişini ve hayal kırıklıklarını unutmaya çalışan Engin hem de bir zamanlar Aysel'in fakültedeki görevinden atılmasına neden olan ve artık delirmiş muhbir Cemil, Danimarka' da “siyasi mülteci” olarak yaşamaktadır. Engin, tesadüfen tanıştığı Cemil'in doktoru Bernt ile konuşmasında geçmişin “tutsaklığından” neden kurtulamadığını sorgular $(H, 159)$. Bu noktada, romanın vurguladığı delirmek unutmaktır teması, Engin'in "Hayır, delirmedim. Çünkü hâlâ hatırlıyorum.” $(H, 155)$ sözlerinde açığa çıkar. Doktor Bernt'in, artık geçmişini hatırlamayan Cemil için; "Deliler hatırlamazlar. Yurttaşınız için hatırlamak, iyileşmenin belirtisi olacaktır." $(H, 155)$ sözleri de unutmanın delirmek ile eşdeğerliği fikrini güçlendirir. Doktor'un, "niyetlerinin gizli hiçbir yanı kalmamış. Aklında ne varsa onu yapıyor. 
Herkesin gözü önünde.” $(H, 160)$ diye tanımladığı eski muhbir Cemil, aslında en trajik son olarak sunulan bütün geçmişi unutmak ya da delirmek ile bir bakıma cezalandırılmıştır. Ricoeur'ün travma sonucu unutma olarak tanımladığı "bloklanmış hafıza” durumu (2004, s.444) artık Cemil'in hiçbir şekilde yaşamda yer edinmemesi ve bir kimliğe sahip olmaması anlamına gelmektedir.

Unutmaya bir tür kurtuluş olarak tutunmaya çalışan Engin ise Aysel'in onu çalıştığı yaşlılar yurdu ziyaretinde hatırlama ile gelen bir epifani yaşar. İlk başta "buz gibi" $(H, 185)$ geçen yıllar sonraki buluşmaları, Engin'in aslında Aysel'le ilişkisinin "bir tarih bağı” $(H, 210)$ olduğunu anlamasıyla birlikte bir kimliğe bürünür. Engin, Aysel'le aynı tarihi yaşadığını, onunla duygu ve akıldan oluşan bir lezzeti tattığını fark eder: “[B]ir ülkenin değilse de kendi tarihimizi kendi ellerimizle yazdık." $(H, 198)$ Bu bağlamda Ağaoğlu, hem roman olaylarını "önceleyen tarihsel dönemlere" hem de "gelecek zamana göndermeler" yapma yolunu izler (Ağaoğlu, 1993, s.186) ve geçmişle geleceği birleştiren bir hatırlama ritüeli sunar. Özellikle son romanda Aysel, gelecek nesillerin onda bir tarih görmesi ile bağdaştırılır. Asistanı Alev’in sözleriyle “Onda, bir kuşağın, o kuşaktan bir avuç insanın hem onurlu hem çok acıklı-gülünçlü serüveni” yankılanmaktadır $(H, 209)$. Geçmiş ile gelecek arasında bir bağ kurmayı amaçlayan Aysel'in geçmişteki aydın intiharlarını incelemesinin sebebi de "geleceğin başkaldırı nedenleri ne olacak diye..." $(H, 212)$ sorgulamasıdır. Bireysel ya da toplumsal bir çıldırı hâlinden kurtulmanın tek yolu bu nedenle hafizayı yeniden kurmak, onu yinelemek olarak verilir.

\section{Sonuç: Delilikten 'Yeni İnsan'a}

Ağaoğlu, tarih, hafiza ve kimlik üçgeninde yazdığı üçlemesinin reddiyeci bir tutumla yazdığı son romanını yine de umutsuz olarak bitirmez. Umut vaat ederek "özgürlük ya da Yeni İnsan" anlamına geldiği söylenen $(H, 295)$; "Hep yirmi yaşında. Yine hiç bozulmamış duru bakışları onun. Yine tutku. Yine inanç. Düş.” $(H, 8)$ olarak tanımlanan; muğlak fakat romanda güçlü bir yer edinen "Yenins"; gençlerin, geleceğin, başkaldırının ve umudun bir temsili olarak sunulur. Aysel'in geçmiş ile birlikte hatırladığı Yenins, aslında geçmiş ve gelecek arasında bir bağ kuran soyut ve hipotetik bir karakterdir. Yenins, "ancak geçmişle görünür olurum" $(H, 298)$ der ve Aysel'e bir gün sandala binip, "sesi yarıp” birlikte gideceklerini söyler $(H, 27)$. Nitekim romanın "Gündoğumu” adlı bölümünde, Aysel'in ödül törenine gelmemesi üzerine onu aramaya giden isimsiz Yazar, denizde sisin içindeki "belli belirsiz bir aydınlıkta" giden bir sandal ile içinde "orta yaşlarda hatta yaşlıca bir kadın”ın Yenins ile konuştuğunu aktarır. Aysel ile Yenins arasındaki bu son konuşma üçlemenin savunduğu; ancak tarih ve hafıza yaratımının bireysel ve toplumsal kimliği ve böylece geleceği yaratabileceği fikrini pekiştirmektedir. Aysel'in yeni bir incelemeye başlamayı, yeni insanın yüzünü görmeyi amaçladığını söylemesi üzerine Yenins şöyle cevap verir: “Ancak geçmişle, sizinle görünür olabilirim. Siz bunun için gereklisiniz bana.” (H, 298) Bu bağlamda, Ağaoğlu'nun tasarladığı Yeni İnsan, geçmişine ve hatıralarına geri dönebilen, geçmişin gerektiği yerde yasını tutup, gerektiği yerde onu affedebilen, böylece yeni bir tarih ve benlik yaratan birey olarak sunulur. Aysel, duyduğu "büyük üzüntü, hatta öfke ve başkaldırıyı dile getirebilmek" $(H, 10)$ çabasının sonuna gelmiş olarak "yazılmış tarihini”" 
burada bitirirken Yazar “Tek bir an'ın, o en kısa sürenin romanını yazmak ister”; oysa Yazar'ın sözleriyle, “an'lar yazılamaz” ( $H, 299)$. Üstkurgusal bir tartışma ile sonlanan roman, herhangi bir anlatının her zaman bir geçmişle bağlantılı olduğunu söylemekte; hafızası, hatırası, geçmişi olmayan hiçbir anın da anlamlı olamayacağını öne sürmektedir.

Sonuç olarak, Ölmeye Yatmak romanıyla başlayan, bireyin kendi tarihini ve bu tarihin toplumsal tarih ile bağını kuran hafıza olgusu, Bir Düğün Gecesi’nde karakterlerin bireysel hafızalarıyla yeniden yüzleşmek zorunda kalmalarına evrilir. Yüzleşmeyi gerçekleştiremeyen bireylerin kimliklerini ve benliklerini de sağlıklı bir şekilde oluşturamamalarına okuru tanık eden Ağaoğlu, hafızanın bireysel ve toplumsal tarih ile bağının koparılmaması gerektiği üzerinde 1srarla durmuştur. Bireysel ve toplumsal amneziye karşı hatırlamayı ve böylece geçmişe karşı adil olmayı savunan hafiza etiğini yansıtan bu romanlar, edebiyatın "hafıza yapma" işlevini de bir kere daha ortaya koymaktadır. Bu bağlamda, üçlemenin son romanı Hayır...'ın sonunda ironik bir şekilde yankılanan, Aysel'in "Hayır, hiçbir şey hatırlamıyorum sayın konuklar, hiç!” (H, 303) sözlerinin eşliğinde, Ağaoğlu'nun Dar Zamanlar üçlemesi geçmişi ziyaret edip hafızayı yinelemek için kurulan bir anıt olarak hatırlanmalıdır.

\footnotetext{
Hakem Değerlendirmesi: Dış bağımsız.

Yazar Katkıları: Çalışma Konsepti/Tasarım- S.A., T.A.; Veri Toplama- S.A., T.A.; Veri Analizi/Yorumlama- S.A., T.A.; Yazı Taslağı- S.A., T.A.; İçeriğin Eleştirel S.A., T.A.; İncelemesi- S.A., T.A.; Son Onay ve Sorumluluk- S.A., T.A. Çıkar Çatışması: Yazarlar çıkar çatışması bildirmemiştir.

Finansal Destek: Yazarlar bu çalışma için finansal destek almadığını beyan etmiştir.
}

Peer-review: Externally peer-reviewed.

Author Contributions: Conception/Design of Study- S.A., T.A.; Data Acquisition- S.A., T.A.; Data Analysis/ Interpretation- S.A., T.A.; Drafting Manuscript- S.A., T.A.; Critical Revision of Manuscript- S.A., T.A.; Final Approval and Accountability- S.A., T.A.

Conflict of Interest: The authors have no conflict of interest to declare.

Grant Support: The authors declared that this study has received no financial support.

\section{KAYNAKÇA/REFERENCES}

Abakan, A. (Yapımc1). (1993). Arşiv Odası: Adalet Ağaoğlu ile Söyleşi. BBC Türkçe. Erişim adresi: https:// www.youtube.com/watch?v=gsPEpbOEPCA.

Ağaoğlu, A. (1993). Karşılaşmalar (1984-1992). İstanbul: Yapı Kredi Yayınları.

Ağaoğlu, A. (1996). Başka Karşılaşmalar: Denemeler-Değiniler-Söyleşiler (1993-1996). İstanbul: Yap1 Kredi Yayınları.

Ağaoğlu, A. (2004). Damla Damla Günler (1969-1977). İstanbul: Alkım Yayınevi.

Ağaoğlu, A. (2020). Ölmeye Yatmak-Dar Zamanlar I. İstanbul: Everest Yayınları.

Ağaoğlu, A. (2020). Bir Düğün Gecesi-Dar Zamanlar II. İstanbul: Everest Yayınları.

Ağaoğlu, A. (2020). Hayır...-Dar Zamanlar III. İstanbul: Everest Yayınları. 
Alver, A. (2013). Postmodern Responses to the September 12th 1980 Military Coup D'état in Turkish Literature. TUDED, XLVIII, 1-22. Erişim adresi: https://www.acarindex.com/dosyalar/makale/ acarindex-1423905837.pdf.

Blustein, J. (2008). The Moral Demands of Memory. New York: Cambridge University Press.

Blustein, J. (2017). A Duty to Remember. In S. Bernecker and K. Michaelian (Eds.), The Routledge Handbook of Philosophy of Memory (pp.351-364). New York: Routledge.

Can, E. G. (Yapımc1). (2019). Atatürk Kültür Merkezi Başkanlı̆̆ı: Adalet Ağaoğlu ile Röportaj. Erişim adresi: https://www.youtube.com/watch?v=t2iYvm0MPIE.

Cuşa, H. (2017). Adalet Ağaoğlu'nun Dar Zamanlar Dörtlemesine Anlatıbilimsel Bir Yaklaşım. (Doktora Tezi). Çukurova Üniversitesi, Adana.

Erll, A. ve Rigney, A. (2006). Literature and the Production of Cultural Memory: Introduction. European Journal of English Studies, 10(2), 111-115. Erişim adresi: http://www.let.leidenuniv.nl/pdf/geschiedenis/ EJES\%20Intro\%20final.pdf

Erll, A. (2012). Memory in Culture. Trans. S. B. Young. Londra: Palgrave Macmillan.

Eronat, K. (2004). Adalet Ağaoğlu İnsan ve Eser. (Doktora Tezi)). Dicle Üniversitesi, Diyarbakır.

Halbwachs, M. (1992). On Collective Memory. Trans. L. A. Coser. Londra: The University of Chicago Press.

Jacoby, R. (1975). Social Amnesia: A critique of conformist psychology from Adler to Laing. Boston: Beacon Press.

Lachmann, R. (2004). Cultural memory and the role of literature. European Review, 12(2), 165-178.

Margalit, A. (2002). The Ethics of Memory. Londra: Harvard University Press.

Mendeloff, D. (2004). Truth-Seeking, Truth-Telling; and Postconflict Peacebuilding: Curb the Enthusiasm?. International Studies Review, 6(3), 355-380.

Nietzsche, F. (1989). On the Genealogy of Morals. Trans. W. Kaufmann. New York: Vintage Books.

Ricoeur, P. (2002). Memory and Forgetting. In R. Kearney and M. Dooley (Eds.), Questioning Ethics: Debates in Contemporary Philosophy (pp.5-12). New York: Routledge.

Ricoeur, P. (2004). Memory, History and Forgetting. Trans. K. Blamey and D. Pellauer. Londra: The University of Chicago Press.

Rieff, D. (2016). In Praise of Forgetting: Historical Memories and its Ironies. New Haven ve Londra: Yale University Press.

Topaloğlu, Y. (2005). Adalet Ağaoğlu'nun Çağdaş Türk Romanındaki Yeri. (Doktora Tezi). Trakya Üniversitesi, Tekirdağ.

Uğurlu, S. B. (2003). Adalet Ağaoğlu'nun Hayatı, Roman ve Hikâyeleri Üzerine Bir Araştırma. (Doktora Tezi). Yüzüncü Y11 Üniversitesi, Van.

Volf, M. (2006). The End Of Memory: Remembering Rightly in a Violent World. Cambridge: William B. Ferdmas Publishing. 
